\title{
Limited effects of source population identity and number on seagrass transplant performance
}

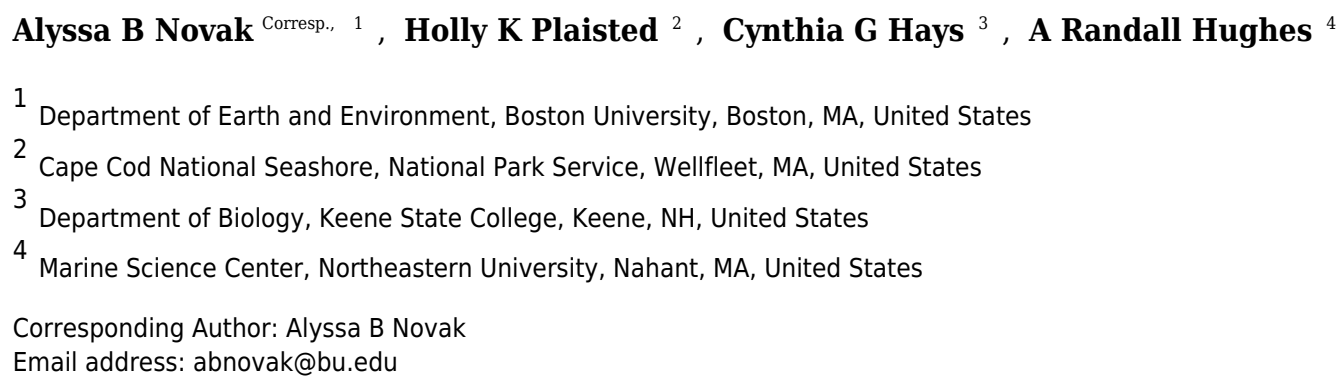

Global declines in coastal foundation species highlight the importance of effective restoration. In this study, we examined the effects of source population identity and diversity (one vs. three sources per plot) on seagrass (Zostera marina) transplant success. The field experiment was replicated at two locations in Massachusetts with adjacent natural $Z$. marina beds to test for local adaptation and source diversity effects on shoot density. We also collected morphological and genetic data to characterize variation within and among source populations and evaluate whether they were related to performance. Transplants grew and expanded until six months post-transplantation, but then steadily declined at both sites. Prior to declines, we observed variation in performance among source populations at one site that was related to morphological traits: the populations with the longest leaves had the highest shoot densities, whereas the population with the shortest leaves performed the worst at six months posttransplantation. In addition, multiple source plots at this same transplant site consistently had similar or higher shoot densities than single source plots, and shoots from weakperforming populations showed improved performance in multiple source plots. We found no evidence for home site advantage or benefits of population-level genetic variation in early transplant performance at either site. Our results show limited effects of source population on early transplant performance and suggest that factors (e.g., morphology) other than home site advantage and population genetic variation serve a role. Based on our overall findings that transplant success varied among source populations and that population diversity at the plot level had positive but limited effects on individual and plot performance, we support planting shoots from multiple source sites in combination to enhance transplant success, particularly in the absence of detailed information on individual source characteristics. 
1 Title: Limited effects of source population identity and number on seagrass transplant

2 performance

3

4 Alyssa B. Novak ${ }^{1}$, Holly K. Plaisted ${ }^{2}$, Cynthia G. Hays ${ }^{3}$, A. Randall Hughes ${ }^{4}$

$5{ }^{1}$ Department of Earth and Environment, Boston University, Boston, MA, USA

$6 \quad{ }^{2}$ Cape Cod National Seashore, US National Park Service, Wellfleet, MA, USA

$7 \quad{ }^{3}$ Department of Biology, Keene State College, Keene, NH, USA

$8 \quad{ }^{4}$ Marine Science Center, Northeastern University, Nahant, MA, USA

9

10 Corresponding Author:

11 Alyssa B. Novak ${ }^{1}$

12

13 Email address: abnovak@bu.edu

14

15

16

17

18

19

20

21

22 


\section{Abstract}

25 Global declines in coastal foundation species highlight the importance of effective restoration. In this study, we examined the effects of source population identity and diversity (one vs. three sources per plot) on seagrass (Zostera marina) transplant success. The field experiment was replicated at two locations in Massachusetts with adjacent natural Z. marina beds to test for local adaptation and source diversity effects on shoot density. We also collected morphological and genetic data to characterize variation within and among source populations and evaluate whether they were related to performance. Transplants grew and expanded until six months posttransplantation, but then steadily declined at both sites. Prior to declines, we observed variation in performance among source populations at one site that was related to morphological traits: the populations with the longest leaves had the highest shoot densities, whereas the population with the shortest leaves performed the worst at six months post-transplantation. In addition, multiple source plots at this same transplant site consistently had similar or higher shoot densities than

37 single source plots, and shoots from weak-performing populations showed improved performance in multiple source plots. We found no evidence for home site advantage or benefits of population-level genetic variation in early transplant performance at either site. Our results show limited effects of source population on early transplant performance and suggest that

41 factors (e.g., morphology) other than home site advantage and population genetic variation serve 42 a role. Based on our overall findings that transplant success varied among source populations 43 and that population diversity at the plot level had positive but limited effects on individual and 44 plot performance, we support planting shoots from multiple source sites in combination to enhance transplant success, particularly in the absence of detailed information on individual 46 source characteristics. 


\section{Introduction}

48 Ecological restoration is the process of assisting the recovery of ecosystems that have been

49 damaged, degraded, or destroyed. One critical component of a successful restoration is the

50 selection of an appropriate source population (Kettenring et al., 2014; van Katwijk et al., 2016),

51 which can ensure population establishment and long-term success. Source selection may be

52 determined by practical considerations such as cost and/or the availability of plants, but ideally it

53 will be guided by ecological theory (Montalvo et al., 1997). Kettenring et al. (2014) recently

54 highlighted three approaches for source selection: (1) planting from populations with preferred

55 traits (the cultivar approach); (2) planting from local populations thought to be adapted to

56 environmental conditions (the local adaptation approach); (3) planting genetically diverse

57 mixtures (the genetic diversity approach). Although there is evidence in support of each of these

58 approaches, few restoration efforts have explicitly tested their relative importance in contributing

59 to successful initial establishment (Kettenring et al., 2014).

60 Seagrasses are an important foundation specis that provide key ecosystem functions in

61 coastal and estuarine systems. However, declines in the abundance and distribution of

62 seagrasses along the world's developed coastlines threaten the health and sustainiability of the

63 systems that rely on these species (Orth et al., 2006). Waycott et al. (2009) estimated that a

64 minimum of $29 \%$ of the known global extent in the distribution of seagrasses has been lost since

65 1879. Moreover, the International Union for Conservation of Nature (IUCN) Red List of

66 Threatened Species recently classified 10 species of seagrass at elevated risk for extinction and

67 three species as Endangered (Short et al., 2011). To mitigate for seagrass losses, considerable

68 time and effort has been spent developing methodologies to improve restoration success rates,

69 including models to facilitate the selection of transplant sites (e.g. Short et al., 2002a; Biber et 
70 al., 2008) and new planting techniques (e.g. Calumpong \& Fonseca, 2001; Lee \& Park, 2008;

71 Zhou et al., 2014). Despite advances in these areas, restoration success rates are still low and

72 variable (Fonseca et al., 1998; Cuhna et al., 2012; Bayraktarov et al., 2016).

73 The majority of seagrass restorations to date have focused on eelgrass (Zostera marina), a

74 species found in temperate waters along both coasts of the United States as well as throughout

75 Europe and eastern Asia (Green \& Short, 2003; van Katwijk et al., 2016). Eelgrass shows

76 considerable physiological and morphological variation across populations and individual

77 genotypes (Hughes et al., 2009; Tomas et al., 2011; Salo et al., 2014; Salo et al., 2015); thus,

78 some populations may possess traits that make them more resilient to the transplanting process

79 than others. There is some evidence that population-level plant traits serve a role in transplant

80 success: Van Katwijk et al. (1998) found that two of five Z. marina populations failed to

81 establish in a mesocosm transplant experiment and that morphology (shoot size) was one factor

82 related to transplant success. Likewise, Lewis and Boyer (2014) found differences in growth

83 characteristics of two sources transplanted into a bare restoration site.

Current seagrass restoration guidelines suggest selecting source populations that are

85

nearby to the transplant site and grow in comparable environments (i.e., are locally adapted to environmental conditions at the transplant site; Addy, 1947; Calumpong \& Fonseca, 2001; van Katwijk et al., 1998; Katwijk et al., 2009). Although there is evidence for local adaptation in seagrases, few seagrass trials have explicitly tested the strength and consistency of this phenomenon as an approach for source selection. For example, Hämmerli and Reusch (2002) showed that eelgrass shoots produced significantly more biomass when transplanted back into their native site than when transplanted to a different location (i.e., home site advantage). In addition, Van Katwijk et al. (2016) showed the proximity of source populations to restoration 
93 sites, often used as a proxy for similar environmental conditions, was positively correlated with

94 the performance of seagrass restoration trials.

95 Given existing variation in functional traits in eelgrass (Hughes et al., 2009; Tomas et al.,

96 2011; Salo et al., 2015), planting shoots from multiple source populations would seem like a

97 reasonable approach to increasing transplant success (analogous to positive effects of genetic and

98 species diversity; Hughes et al., 2008, Cardinale et al., 2012, Kettenring et al., 2014). In fact,

99 several studies with eelgrass have shown positive effects of within species genetic diversity on

100 transplant success and productivity (Williams 2001; Hughes \& Stachowicz, 2004 \& 2011;

101 Reusch et al., 2005; Reynolds et al., 2012). Most of these experiments used individual plants of

102 known genetic identity; because of the expense and time involved, this level of detail is generally

103 not feasible for restoration efforts. However, the number of source populations may serve as a

104 proxy for genetic diversity, facilitating transplant success. For example, Reynolds et al. (2012)

105 conducted a seed-based restoration experiment testing the performance of plots created with

106 seeds from single vs. multiple source sites, demonstrating a positive relationship between

107 resulting plot-level genetic diversity (measured as allelic richness) and plant survival,

108 production, and habitat provision. Whether source diversity of adult transplants has similar

109 positive effects on transplant success has not yet been tested.

110 In this paper, we examined the effects of source identity and diversity (one versus three

111 source populations in a plot) on eelgrass transplant success over the course of one year. Our

112 experiment was replicated at two sites that also served as source sites to test for local adaptation

113 (home site advantage) and the generality of diversity effects. Morphological and genetic data

114 were also collected to characterize variation within and among source populations and relate it to 
115 transplant performance. We hypothesized that both home site advantage and source diversity

116 would have a positive effect on eelgrass shoot density.

117

118 Methods

119 Source Populations

120 Zostera marina shoots were collected from four source populations in Massachusetts with a

121 range of environmental conditions (Table 1; Fig 1.). Approximately 500 vegetative shoots were

122 haphazardly collected at a depth of $1.5 \mathrm{~m}$ mean low water (MLW) along a $50 \mathrm{~m}$ transect oriented

123 parallel to shore from each of the four locations (source sites) in November 2013. Shoots were

124 removed by uprooting three to five $\mathrm{cm}$ of the rhizome and snapping the rhizome at the base of

125 plants. Harvested eelgrass was cleaned of epiphytes and immediately stored in aerated or

126 flowing seawater for less than $72 \mathrm{hrs}$ before being transplanted at sites (Davis \& Short, 1997).

127 Morphological Variation

128 Morphological variation was characterized within and across our source populations. The

129 following traits were measured on 25 representative shoots collected from each source site that

130 were not used in our test-transplanting experiment: the number of leaves per shoot, the above

131 ground and below ground wet weight of each shoot, the distance between nodes on the rhizome

132 (internode length), and the length, width, sheath length, and weight of the youngest fully mature

133 leaf. We also measured leaf length on shoots in each plot during the experiment at six months

134 post-transplantation.

135 Genetic Variation

136 Genetic variation within and among our source populations was characterized by analyzing DNA

137 microsatellite variation for a subset of 25 shoots collected from each site. We extracted genomic 
138 DNA from $\sim 200 \mathrm{mg}$ of silica-dried leaf tissue using E.N.Z.A. ${ }^{\circledR}$ SP Plant DNA kit, following

139 manufacturer's protocol (Omega Bio-tek, Inc.). Nine microsatellite loci were amplified via three

140 multiplex PCRs for each sample (see Table S1 in supplementary materials). All PCRs were run

141 with the following conditions: 5 min denaturation at $95^{\circ} \mathrm{C}$, followed by 28 cycles of $90 \mathrm{~s}$

142 annealing at $60^{\circ} \mathrm{C}, 30 \mathrm{~s}$ extension at $72^{\circ} \mathrm{C}$, and $30 \mathrm{~s}$ denaturation $95^{\circ} \mathrm{C}$, followed by a terminal

143 extension of $30 \mathrm{~min}$. Products were checked on 1\% agarose gels before sending for fragment

144 analysis via capillary electrophoresis at the DNA Analysis Facility at Yale University.

145 Test-Transplanting Field Experiment

146 Harvested eelgrass shoots were used in a field experiment and monitored for 11 months to

147 determine the effects of source population identity (Nahant, East Harbor, Pleasant Bay, West

148 Yarmouth; Fig. 1) and diversity (one vs. three source populations in a plot) on eelgrass

149 performance (measured as shoot density). The experiment was replicated at two sites (East

150 Harbor and Pleasant Bay; Table 1; Fig. 1; Fig. S1) to test for evidence of local adaptation and the

151 generality of diversity effects. At East Harbor, our experiment was established approximately

$152 \sim 200 \mathrm{~m}$ from the closest natural seagrass bed, whereas at Pleasant Bay we used large bare

153 patches within the natural bed. We used a modified version of the TERF restoration technique

154 (Fonseca et al. 1998; Short et al. 2002b; Leschen et al. 2009) to maximize the relevance of our

155 results for future efforts. Shoots were attached with jute string to the cross-hairs of gridded

156 frames ( $60 \mathrm{~cm}$ x $60 \mathrm{~cm}$; 2 shoots per cross-hair; 30 shoots per frame) made of PVC and jute

157 string. Single source treatments contained 30 shoots from one of the four source populations,

158 whereas multiple source treatments contained 10 shoots from three randomly-selected source

159 populations out of the four source populations. Treatments were assigned to plots in a complete

160 randomized block design, with each block containing the four unique single source 
161 treatments and the four unique multiple source treatments. There were four blocks at each site,

162 resulting in 32 plots per site (Fig. S1). Field experiments were approved by the National Park

163 Service (Permit Number CACO-2013-SCI_0026.

164 All shoots in each plot were counted at each transplant site at four months (March) and

165 then monthly from months six through 11 (May - November). Shoots did not expand outside of

166 each plot and we were able to reliably assign shoots to cross-hairs until June (seven months post-

167 transplantion) for within-plot diversity analyses (see below).

\section{Data Analyses}

169 Morphological variation across source populations prior to the initiation of our experiment was

170 analyzed using a multivariate analysis of variance (MANOVA). The MANOVA indicated

171 significant differences among source populations as well as multicollinearity. One dependent

172 variable (leaf weight) had a partial correlation above 0.7 with leaf width and length and was

173 removed before conducting individual analyses of variance (ANOVA) on the remaining

174 dependent variables. Tukey's HSD post hoc multiple comparisons tests were also performed to

175 identify differences among source populations. The morphology dataset met the assumptions of

176 the Kolmogorov-Smirnov test of normality and the Brown-Forsythe test of equal variance.

177 Morphological variation in leaf length was assessed at six months post-transplantion. To

178 remove covariance due to non-independence within plots, we calculated the mean length of

179 shoots for each source population at each diversity level. We analyzed both transplant sites

180 together using a fully crossed three-factor ANOVA to test whether mean length of shoots varied

181 with transplant site, source population, source diversity, or their interactions.

182 Microsatellite alleles were scored by eye using GENEMARKER V2.6.3 (SoftGenetics,

183 Inc.), and only ramets for which all nine markers were successfully amplified and scored were 
184 used in further analysis $(n=22-23$ per site $)$. To identify genetically unique individuals and 185 assign ramets to genets, we used GENECLONE 2.0 (Arnaud-Haond \& Belkhir 2007). We 186 measured genotypic or clonal richness $(\mathrm{R})$ as $\mathrm{R}=(\mathrm{G}-1) /(\mathrm{N}-1)$, where $\mathrm{G}$ is the number of unique 187 genotypes and $\mathrm{N}$ is the total number of shoots analyzed. We also used GENECLONE 2.0 to 188 calculate two other measures of genotypic diversity, the Shannon index (H') and clonal evenness 189 (ED*). We then removed all repeatedly sampled genets, restricting the data set to unique 190 mulilocus genotypes, and used GENODIVE (Meirmans \& Van Tienderen 2004) to estimate 191 allelic richness, effective number of alleles, expected and observed heterozygosity, and to 192 calculate F-statistics.

193 The influence of source identity and diversity (single source vs. multiple source) on shoot

194 density of the transplanted eelgrass was assessed by analyzing each transplant site separately, 195 using two separate repeated-measures ANOVAs (univariate split-plot approach) on the total 196 number of shoots per plot, with block as a random effect and including all sampling dates 197 (March, May-October). When the interaction between time and treatment (either source identity 198 or source diversity) was significant, we conducted multiple one-way ANOVAs for each 199 sampling date at each site, with treatment as a fixed effect and block as a random factor for months with equal sample sizes. Tukey's HSD post hoc multiple comparisons were performed to

201 identify differences among source treatments. Local adaptation would be indicated if source sites 202 perform better at 'home' than 'away' (e.g., if Pleasant Bay (PB) has higher density at PB than at 203 East Harbor (EH)), or if 'local' sources do better than 'foreign' sources (e.g., if PB has higher 204 density at PB than other source sites). When the ANOVA indicated a significant effect of source diversity, we calculated the 206 net diversity effect by subtracting the expected multiple source density (calculated as the sum of 
207 each component single source divided by three) from the observed multiple source density for

208 each block (Loreau \& Hector 2001). We considered the net diversity effect significant if the $95 \%$

209 confidence intervals did not contain zero. We also conducted a two-factor ANOVA using the

210 lme4 package in $\mathrm{R}$ (Version 3.2.3, R Foundation for Statistical Computing) to test whether the

211 net diversity effect varied by source identity, by experimental site, or by their interaction.

212 The number of shoots per cross-hair collected the first three census periods (four months,

213 six months, and seven months post-transplantion) was analyzed to assess whether shoots from

214 the four source populations differed in their response to within-plot diversity. Covariance due to

215 non-independence of cross-hairs within plots was removed by calculating the mean number of

216 shoots per cross-hair for each source population within each plot; then we calculated the mean

217 for each source population at each diversity level within a given spatial block, thus yielding a

218 single value per spatial block for each source and diversity combination. We analyzed both

219 transplant sites together, using a fully crossed three-factor ANOVA for each of the three census

220 dates to test whether individual shoot survival varied with transplant site, source population,

221 source diversity, or any of their interactions.

222 Statistical analyses were performed using JMP (Version 10.0.2, SAS Institute Inc.) unless

223 otherwise noted.

\section{Results}

226 Morphological Variation

227 MANOVA tests of the variation in eelgrass shoot morphology among source populations at the

228 time of transplantation using the Wilks' Lambda criteria were statistically significant $\left(\mathrm{F}_{[18,257.87]}\right.$

$229=20.60, p<0.0001)$. Subsequent univariate comparisons showed significant differences among 
230 source populations for all traits (Fig. 2; one-factor ANOVA: leaf width, $\mathrm{F}_{[3,96]}=12.85, p<$

2310.0001 ; leaf length, $\mathrm{F}_{[3,96]}=18.50, p<0.0001$; sheath length, $\mathrm{F}_{[3,96]}=49.40, p<0.0001$;

232 internode length, $\mathrm{F}_{[3,96]}=14.01, p<0.0001$; leaves/shoot, $\mathrm{F}_{[3,96]}=22.79, p<0.0001$;

233 above/below ground weight, $\left.\mathrm{F}_{[3,96]}=12.84, p<0.0001\right)$. Nahant shoots had wider leaves, longer

234 leaves (equivalent to Pleasant Bay shoots) and sheaths, and a greater ratio of above ground

235 weight to below ground weight compared to shoots from other sites. West Yarmouth shoots had

236 the shortest leaves and sheaths (equivalent to Pleasant Bay). East Harbor shoots had the longest

237 internode lengths while Pleasant Bay shoots had the shortest. Both Nahant and East Harbor

238 shoots had more leaves per shoot than shoots collected from West Yarmouth or Pleasant Bay 239 (Fig. 2).

240 Leaf length was greater for shoots from Nahant (equivalent to East Harbor) than shoots

241 from Pleasant Bay or West Yarmouth at six months post-transplantation. This pattern was

242 consistent across both transplant sites and diversity plots and there were no interactive effects

243 observed between source, diversity, and/or site (three factor ANOVA: source, $\mathrm{F}_{[3,419.80]}=4.49, p$ $244=0.0077$; site, $\mathrm{F}_{[1,0.20]}=0.01, p=0.9356$; diversity, $\mathrm{F}_{[1,43.58]}=1.40, p=0.2430$; site $\times$ diversity $=$ $245 \mathrm{~F}_{[1,3.14]}=0.10, p=0.7521 ;$ site $\times$ source, $\mathrm{F}_{[3,18.99]}=0.20, p=0.8936$; source $\times$ diversity,

$246 \quad \mathrm{~F}_{[3,75.62]}=0.80, p=0.4953 ;$ source $\times$ diversity $\times$ site, $\mathrm{F}_{[3,48.98]}=0.52, p=0.6678$.

247 Genetic Variation

248 Complete genotypes were obtained for 91 of the 100 shoots analyzed. All nine microsatellite 249 loci used in this study were polymorphic, ranging from two alleles for CT-12 to 11 alleles for 250 ZMC-12075. There were 60 unique genotypes found; none were shared across populations.

251 Both clonal and allelic richness were higher in samples collected from West Yarmouth and

252 Pleasant Bay than the other two source populations (Table 2). However, West Yarmouth and 
253 Pleasant Bay samples differed in the effective number of alleles per locus $\left(\mathrm{N}_{\mathrm{e}}\right)$, which is the

254 number of equally frequent alleles it would take to achieve a given level of gene diversity.

255 Pleasant Bay samples possessed the highest $\mathrm{N}_{\mathrm{e}}$ of the four source populations tested here, and

256 West Yarmouth the lowest, indicating slightly lower heterozygosity and less even distribution of

257 alleles (Table 2). Pairwise comparisons of population differentiation detected significant

258 structure between all pairs of source populations $\left(\mathrm{F}_{\mathrm{st}}, p<0.001\right)$, with the greatest differentiation

259 found between West Yarmouth and East Harbor (Table S2).

260 Shoot Density

261 Transplants grew and expanded until six months post-transplantation, however shoot density

262 steadily declined at both sites from seven months post-transplantation to the end of monitoring

263 (11 months; Fig. 3). When we assessed performance of source populations in single source plots

264 we found an interaction between source population and time on shoot density in East Harbor

265 (repeated measures ANOVA: source, $\mathrm{F}_{3,12.6}=9.26, p=0.0017$; time, $\mathrm{F}_{6,64.44}=99.39, p<0.0001$;

266 time $\times$ source, $\mathrm{F}_{18,64.3}=3.81, p=0.0001$ ): shoot density was similar across sources sites for all

267 months except March and May, when source plots containing shoots from Nahant or East Harbor

268 and Nahant or Pleasant Bay, respectively, exhibited the greatest shoot densities and West

269 Yarmouth the lowest (Table S3; Fig. 3). There was no evidence for home site advantage, as East

270 Harbor shoots did not outperform other source sites in East Harbor. At Pleasant Bay, all single

271 source plots performed similarly, again demonstrating no home site advantage. We observed a

272 significant effect of time, with shoot density gradually declining over the course of the

273 experiment (repeated measures ANOVA: source, $\mathrm{F}_{3,12.08}=0.62$, $p<0.6155 ;$ time, $\mathrm{F}_{6,61.2}=10.25$,

$274 p<0.0001$; time $\times$ source, $\left.\mathrm{F}_{18,61.2}=1.20, p=0.3022\right)$. 

compared the performance of single source and multiple source plots (Fig. 4; repeated measures

\section{7} ANOVA: diversity, $\mathrm{F}_{1,6}=5.87, p=0.0516$; time, $\mathrm{F}_{6,36}=83.53, p<0.0001$; time $\times$ diversity, $\mathrm{F}_{6,36}=2.40, p=0.0468$ ), but only an effect of time at Pleasant Bay (Fig. 4; repeated measures ANOVA: diversity, $\mathrm{F}_{1,5.89}=0.014, p=0.9094 ;$ time, $\mathrm{F}_{6,32.98}=25.94, p<0.0001 ;$ time $\times$ diversity, $\left.\mathrm{F}_{6,32.98}=0.56, p=0.7519\right)$. At East Harbor, shoot density was higher for multiple source plots compared to single source plots in March (four months post-transplantation) and September (10 month post-transplantation; Table S3; Fig. 4). The net diversity effect analysis corroborated these results: there was a positive overall effect of diversity in March (mean $\pm 95 \% \mathrm{CI}=3.25+$ 1.14), but this positive effect was only significant at East Harbor ( site $\mathrm{F}_{1,20}=8.71, p=0.008$ ). In September, the overall diversity effect was not significant because a positive diversity effect in East Harbor was counter-acted by a non-significant diversity effect in Pleasant Bay ( site $\mathrm{F}_{1,24}=$ 7.32, $p=0.01)$.

When we assessed eelgrass performance at the scale of shoots per cross-hair (i.e. within grid), we found that in March the effect of source diversity depended on which source the eelgrass shoots came from (source $\times$ source diversity $\mathrm{F}_{3,40}=4.07, p=0.01$; Fig. 5) in a pattern that was consistent across both transplant sites ( source $\times$ source diversity $\times$ site $\mathrm{F}_{3,40}=1.66, p=$ 0.19; Table 3a). Shoots from Pleasant Bay and West Yarmouth performed significantly better in multiple source than single source plots (a priori contrasts, $p=0.001$ and $p=0.0003$ ), whereas

294 shoots from Nahant and East Harbor performed equivalently regardless of the diversity of 295 neighboring shoots $(p>0.1)$. As with the grid-level analysis above, this pattern changed over 296 time. By May and June, shoot performance depended largely on the interactive effects of source 297 identity and site (source $\times$ site; May: $\mathrm{F}_{3,44}=7.57, p=0.0003$; June: $\mathrm{F}_{3,48}=4.19, p=0.01$ ), with 
298 no support for a home site advantage for transplants at either location or date (Fig. S3). No

299 significant effect of source diversity was detected at the shoot level after the first census (Tables

$3003 b \& 3 c$ ), although in June there was a marginal effect that differed between the sites (diversity $\times$

301 site $\mathrm{F}_{1,48}=3.76, p=0.06$ ), such that source diversity tended to have a positive effect on shoot

302 density at Pleasant Bay but no effect at East Harbor (Fig. S4).

303

304 Discussion

305 Our study examined the effects of seagrass source identity and diversity on Z. marina transplant

306 success in a field experiment that was replicated at two locations that also served as source sites

307 to test for local adaptation and the generality of source diversity effects on shoot density. We

308 showed that transplants grew and expanded until six months post-transplantation, however, after

309 that period shoot density steadily declined at both sites until the end of our experiment. Prior to

310 declines, we found that source identity was important for early transplant performance at our

311 East Harbor site. Single source plots containing eelgrass from West Yarmouth had the lowest

312 shoot densities, whereas plots containing eelgrass from Nahant and Pleasant Bay exhibited the

313 greatest shoot densities at six months post-transplantation. In contrast, source identity did not

314 significantly influence performance at the Pleasant Bay site. Thus, our results support the

315 hypothesis that some seagrass populations may be more suitable sources for transplanting than

316 others (Meinesz et al., 1993; van Katwijk et al., 1998), yet suitability will likely vary across sites.

317 There are several characteristics of source populations that could have contributed to the

318 variation in performance we observed before our plots declined. Proximity of source

319 populations to a restoration site has been linked to increased seagrass transplant success (van

320 Katwijk et al., 2016), potentially due to similarity in environmental conditions among nearby 
321 sites and local adaptation of plants to these conditions. By transplanting two source populations

322 within/adjacent to the source site, our experimental design allowed us to test for local adaptation

323 of two source populations. We showed that shoots transplanted back to their home site did not

324 consistently outperform shoots from other source sites (i.e., no local vs. foreign advantage), nor

325 did shoots transplanted back to their home site outperform shoots from that same population

326 planted in a different site (i.e., no home vs. away advantage). In addition, we found no clear

327 benefits of shoots collected from nearby sites (e.g., East Harbor shoots at the Pleasant Bay site)

328 and/or a clear relationship between shoot performance of transplants and environmental

329 conditions at source sites. Field experiments by Piazzi et al. (1998) also found no evidence for

330 local adaptation in transplants and instead showed that $P$. oceanica shoots from distant beds had

331 higher rhizome growth and ramification than shoots from nearby source sites. Based on the

332 results of our experiment and others, we suggest that source characteristics other than home site

333 advantage and/or geographic proximity to the transplant site may have greater influence on

334 initial transplant success. However, since we did not transplant Nahant or West Yarmouth

335 populations back to their home sites we should not rule out the role of local adaptation in early

336 transplant success. Moreover, potential mismatch between donor traits and the recipient site

337 characteristics may yet become apparent over longer time scales than those of our study. For

338 example, analysis of a Z. noltei restoration experiment four years after transplantation revealed

339 that the new seagrass patches that had appeared in the lagoon since the experiment were

340 genetically distinct from the transplanted shoots, and likely recruited from remnant patches of the

341 original population (Jahnke et al., 2015).

342 Morphological variation among seagrass populations can be due to environmental and/or

343 genetic factors and has measureable effects on community composition, structure, and function 
344 (Kuo and den Hartog, 2006; Hughes et al., 2009). In our study, we documented a diversity of

345 morphologies among source populations, characterized by significant variation in internode

346 length, leaf length, sheath length, and leaf width. Of our source sites, Nahant had on average the

347 longest leaves both initially as well as up to six-months post-transplantation, and plots from

348 Nahant had among the highest densities during this same time period. Alternatively, single

349 source plots from West Yarmouth, the source population with the shortest leaves initially,

350 performed the worst during this same time period. Van Katwijk (1998) also observed a

351 relationship between shoot performance and morphology, however, the authors found that

352 smaller-sized shoots (shoots with shorter and narrower leaves) outperformed larger shoots when

353 grown in a controlled outdoor mesocosms over a two-year period. Based on our results, we

354 suggest that the utility of morphological traits as an indicator of source population performance,

355 at least for initial post-transplant survival, should be further assessed.

356 Another criterion suggested for source site selection is the genetic diversity of the donor

357 population. In clonal plants such as Z. marina, genetic variation can be measured in different

358 ways, including the diversity of genotypes (clones), and the diversity of genes (alleles) found in

359 individuals in a population or plot. While these measures are correlated at the lowest levels of

360 genetic variation (see Massa et al., 2013), both types of diversity may contribute independently

361 to the positive relationship between seagrass genetic diversity and ecosystem function

362 increasingly documented in manipulative studies (e.g. Hughes \& Stachowicz, 2004; Hughes \&

363 Stachowicz, 2011; Reusch et al., 2005; Reynolds et al., 2012). Heritable genetic variation in

364 functional traits largely determines a population's evolutionary potential; thus planting

365 individuals from a more diverse source may promote population persistence over a longer time

366 frame (see, e.g., Reynolds et al., 2012). A third measure of genetic diversity, heterozygosity, or 
367 the diversity of alleles contained within an individual, may also indicate a good source

368 population; heterozygosity may not reflect total allelic diversity at the population scale, but

369 greater heterozygosity can have immediate benefits for the fitness of individual eelgrass ramets

370 and population growth (Williams, 2001; Hammerli \& Reutsch, 2003). In this study, we found no

371 correlation between genetic or genotypic richness in our four source populations and their

372 subsequent growth and survival when transplanted into single-source plots. Notably, samples

373 from two of our four sources, West Yarmouth and Pleasant Bay, exhibited similarly high

374 genotypic diversity, genotypic richness, and allelic richness, but differed in transplant

375 performance: West Yarmouth showed the lowest performance of the four sources overall (across

376 both transplant sites and over time), while shoots from Pleasant Bay faired better, significantly so

377 for some sampling periods at East Harbor. On the other hand, mean heterozygosity and its

378 correlate, effective allelic richness, were lowest in the (poor performing) samples from West

379 Yarmouth. However, heterozygosity was not a consistent predictor of source performance, at

380 least over the range of genetic diversity we were able to test here.

381 The number of source populations used in restoration may function as a proxy for

382 genetic, morphological and functional diversity of transplants. Although genetic diversity within

383 each source population did not clearly predict transplant performance, we did detect a positive

384 effect of increasing source population number at some points during the experiment. While the

385 strength of this effect varied across experimental sites and through time, multiple source plots

386 consistently performed as well or better than single-source plots (i.e., there was never a negative

387 effect of source number). Our per cross-hair analysis suggests that the positive effects of

388 diversity were not simply the result of the presence of high-performing individual sources (also

389 known as a sampling effect; Hector, 1998). Rather, the performance of otherwise weak- 
390 performing source populations (e.g., West Yarmouth) improved in multiple source plots. The

391 positive effects of plot-level source diversity in our study are consistent with findings of

392 increased production with higher plot-level genotypic richness in Z. marina (Hughes \&

393 Stachowicz, 2004; Hughes \& Stachowicz, 2011; Reusch et al., 2005). Taken together, they

394 suggest that it is genetic diversity at the plot scale (i.e., the scale at which individual plants

395 interact with one another), and not at the population level, that is most likely to confer the

396 expected benefits of biodiversity. Furthermore, prior experiments with Z. marina have found

397 that effects of genetic diversity increased through time (Hughes \& Stachowicz, 2011; Reynolds

398 et al., 2012). Thus, we suggest that restoration efforts consider planting eelgrass shoots from

399 multiple sources in combination when feasible, rather than planting shoots from a single source,

400 to increase the chances of transplant success. Ort et al. (2012) has also suggested using multiple

401 populations (in close proximity) based on the population structure of Z. marina in estruries.

402 However, of key concern would be the distance over which source populations should be

403 combined, as mixing historically isolated populations can lead to negative consequences (e.g.

404 outbreeding depression) if populations are sufficiently genetically differentiated (see review by

405 Hufford \& Mazer, 2003). Thus sources should be selected from within a relatively nearby area

406 or, ideally, a defined management unit (Olsen et al., 2014). Given the overall low survival of

407 transplants and relatively short time frame of this study, our results capture only asexual

408 expansion/contraction of genets, not sexual reproduction. More importantly, while the

409 signficiant pairwise $\mathrm{F}_{\mathrm{st}}$ values indicate genetic subdivision among the four source populations, a

410 recent molecular study of eelgrass populations in southern New England and New York indicates

411 that the more substantial break in population structure occurs south of Cape Cod, and that the

412 four sites used here are part of the same putative metapopulation (Short et al., 2012). 
Shoot density at both experimental sites gradually declined through time after six months,

414 with very low abundance one year post-transplanting. Several factors may have contributed to

415 this decline. Water quality measurements recorded near our field experiments by CCNS-NPS

416 indicate that by the end of May (six months post-transplantation) water temperatures in Pleasant

417 Bay and East Harbor consistently exceeded thresholds for optimal photosynthesis and growth

418 (20-23.3 ${ }^{\circ} \mathrm{C}$; Lee et al., 2007; Staehr \& Borum, 2011), with temperatures as high as $27^{\circ} \mathrm{C}$ during

419 the summer months. Thus, the high water temperatures could have contributed to the high

420 mortality of eelgrass transplants during this period. In addition to high water temperatures, East

421 Harbor experienced a macroalgal bloom (Cladophoroa spp) that appeared in July and persisted

422 through September. The bloom carpeted the transplants, and undoubtedly limited the light

423 available, thus limiting photosynthesis, but had no visible impact on the natural beds in the area.

424 The Pleasant Bay site did not experience any algal blooms, however disturbance by horseshoe

425 crabs was observed in the area. Furthermore, the frames that we used for planting facilitated

426 plant establishment initially, but they appeared to inhibit rhizome development at later stages of

427 the experiment, uprooting the plants at some cross hairs and causing shoot mortality. While

428 frames have been shown to have a benefit during the initial stages of transplanting, recent

reviews of seagrass restoration efforts have noted a decline in the benefit of frames through time

430 and suggest removing frames following initial plant establishment (van Katwijk et al., 2016).

431 Lastly, the relatively low number of shoots $(<1000)$ used at each of our sites may have hindered

432 long-term plant establishment, as the magnitude of planting effort is a primary predictor of

433 seagrass transplant success (van Katwijk et al., 2016).

434 The goal of this study was to explore how the identity and diversity of source populations

435 may influence eelgrass transplant success. Although survival of all transplants was ultimately 
436 very low at both sites, we did find that early transplant success varied among source populations,

437 and that the pattern of performance was inconsistent with local adaptation. This finding may

438 reflect the short-time scale of our study, as local adaptation is predicted to be more important in

439 long-term plant establishment (Kettenring et al., 2014; Jahnke et al., 2015). Our results support

440 the importance of morphological characteristics of the source population (i.e., shoot size) in early

441 transplant success (van Katwijk et al., 2009) suggesting that planting sources with particular

442 traits (similar to the cultivar approach) may benefit rapid plant establishment (Kettenring et al.,

443 2014). Although we did not explicitly manipulate the genotypic richness of source plants, we

444 found limited evidence that population diversity increased individual or plot performance; this

445 pattern was significant at one of the transplant sites for two dates of the seven sampled. Others

446 have suggested using a multi-source approach to further ensure that restored eelgrass beds do not

447 have reduced genetic diversity compared to natural beds (cf, Williams \& Davis, 1996). Based

448 on our overall findings that transplant success varied among source populations, and that

449 population diversity at the plot level had positive but limited effects on indivual and plot

450 performance, we support further tests of the multi-source approach for restorations.

451

452 Acknowledgements

453 We thank K. Benes, F. Choi, T. Hanley, T. McCadden, G. Pacela, T. Rogers, F. Schenck, A.

454 Stanclift, A. Costa, J. Burkhart, and A. Thime for help in the field. We also thank J. Bruno and 455 three reviewers for their comments. 


\section{Literature Cited}

458 Addy CE. 1947. Eel grass planting guide. Maryland Conservationist 24:16-17.

459 Arnaud-Haond S, Belkhir K. 2007. Geneclone: A Computer Program to Analyse Genotypic

460 Data, Test for Clonality and Describe Spatial Clonal Organization. Molecular Ecology

$461 \quad$ Notes 7:15-17.

462 Bayraktarov E, Saunders M, Abdullah S, Mills M, Beher J, Possingham HP, Mumby PJ, 463 Lovelock CE. 2015. The cost and feasibility of marine coastal restoration. Ecological Applications doi: 10.1002/15-1077.

465

466

467

468

469

470

471

472

473

474

475

476

477

478

479

Biber PD, Gallegos CL. 2007. North Carolina (Albermarle-Pamlico Sound): a tool to evaluate water quality impacts on seagrasses. Estuaries and Coasts J CERF 31:177-191.

Bromberg Gedan K, Silliman BR, Bertness MD. 2009. Centuries of human-driven change in salt marsh ecosystems. Annual Review of Marine Science 1:117-141.

Calumpong HP, Fonseca MS. 2001. Seagrass transplantation and other seagrass restoration methods. Pages 425-427 In: Short FT, Coles RG (eds). Global seagrass research methods. Elsevier Science B. V., Amsterdam.

Cardinale BJ, Duffy JE, Gonzalez A, Hooper DU, Perrings C, Venail P, Narwani A, Mace GM, Tilman D, Wardle DA, Kinzig AP, Daily GC, Loreau M, Grace JB, Larigauderie A, Srivastava DS, Naeem S. 2012. Biodiversity loss and its impact on humanity. Nature 486:59-67.

Cabaço S, Apostolaki ET, García-Marín P, Gruber R, Hernandez I, Martínez-Crego B, Mascaro O, Perez M, Prathep A, Robinson C, Romero J. 2013. Effects of nutrient enrichment on seagrass population dynamics: evidence and synthesis from the biomass-density relationships. Journal of Ecology 101:552-1562. 
480 Cunha AH, Marba NN, van Katwijk MM, Pickerell C, Henriques M, Bernard G, Ferreira MA,

481 Garcia S, Garmendia JM, Manent P. 2012. Changing paradigms in seagrass restoration.

482 Society for Ecological Restoration International 20:427-430.

483 Davis RC, Short FT. 1997. Restoring eelgrass, Zostera marina L., habitat using a new

484 transplanting technique: the horizontal rhizome method. Aquatic Botany 59:1-15.

485 Duarte CM. 2002. The future of seagrass meadows. Environmental conservation. 29:192-206.

486 Duke NC, Meynecke JO, Dittmann S, Ellison AM, Anger K, Berger U, Cannicci S, Diele K,

487 Ewel KW, Field CD, Koedam N, Lee SY, Marchand C, Nordhaus I, Dahdouh-Guebas F.

488 2007. A world without mangroves? Science 317: 41-42.

489 Fonseca MS, Kenworthy WJ, Thayer GW. 1998. Guidelines for the conservation and restoration

490 of seagrasses in the United States and adjacent waters. NOAA Coastal Ocean Program

491 Decision Analysis Series No.12.

492 Green EP, Short FT. 2003. World Atlas of Seagrasses. University of California Press, Berkeley, $493 \quad$ California.

494 Hammerli A, Reusch TBH. 2003. Inbreeding depression influences genet size distribution in a 495 marine angiosperm. Molecular Ecology 12:619-629.

496 Hector A. 1998. The effect of diversity on productivity: detecting the role of species

$497 \quad$ complementarity. Oikos 82:597-599.

498 Hufford KM, Mazer SJ. 2003. Plant ecotypes: genetic differentiation in the age of restoration.

$499 \quad$ Trends in Ecology and Evolution 18:147-155.

500 Hughes AR, Stachowicz JJ. 2004. Genetic diversity enhances the resistance of a seagrass

$501 \quad$ ecosystem to disturbance. Proceedings of the National Academy of Sciences 101:8998-

5029002. 
503 Hughes AR, Stachoqicz JJ, Williams SL. 2009. Morphological and physiological variation

$504 \quad$ among seagrass (Zostera marina) genotypes. Population Ecology 159:725-733.

505 Hughes AR, Stachowicz JJ. 2011. Seagrass genotypic diversity increases disturbance response

506 via complementarity and dominance. Journal of Ecology 99:445-453.

507 Jahnke M, Serra IA, Bernard G, Procaccini G. 2015. The importance of genetic make-up in seagrass restoration: a case study of the seagrass Zostera noltei. Marine Ecology Progress

510 Kettenring KM, Mercer KL, Adams CR, Hines J. 2014. Application of genetic diversityecosystem function research to ecological restoration. Journal of Applied Ecology

512 51:339-348.

513 Kuo J, den Hartog C. 2006. Morphology, anatomy, and ultrastructure. In Seagrasses: Biology, 514 Ecology and Conservation. Pages 51-88 In: Larkum AWD, Orth RJ, Duarte CM, (eds). Springer Verlag, Berlin.

Lee KS, Park SR, Kim YK. 2007. Effects of irradiance, temperature and nutrients on growth dynamics of seagrasses: a review. Journal of Experimental Marine Biology and Ecology 350:144-175.

Lee KS, Park JI. 2008. An effective transplanting technique using shells for restoration of Zostera marina habitats. Marine Pollution Bulletin 56:1015-1021.

Leschen AS, Kessler RK, Estrella BT. 2009. Eelgrass restoration used as construction impact mitigation in Boston Harbor, Massachusetts. Massachusetts Division of Marine Fisheries Technical Report TR-37.

524 Lewis JT, Boyer KE. 2014. Grazer functional roles, induced defenses, and indirect interactions: Implications for eelgrass restoration in San Francisco Bay. Diversity 6:751-770. 
526 Loreau L, Hector A. 2001. Partitioning selection and complementarity in biodiversity

527 experiments. Nature 412:72-76.

528 Lotze HK, Lenihan HS, Bourque BJ, Bradbury RH, Cooke RG, Kay MC, Kidwell SM, Kirby

529 MX, Peterson CH, Jackson JBC. 2007. Depletion, degradation, and recovery potential of

$530 \quad$ estuaries and coastal seas. Science 312:1806-1809.

531 Massa SI, Paulino CM, Serrão EA, Duarte CM, Arnaud-Haond S. 2013. Entangled effects of 532 allelic and clonal (genotypic) richness in the resistance and resilience of experimental populations of the seagrass Zostera noltii to diatom invasion. BMC Ecology 13:39.

534 Meinesz A, Caye G, Loques F, Molenaar H. 1993. Polymorphism and development of Posidonia oceanica transplanted from different parts of the Mediterranean into the National Park of Port-Cros. Botanica Marina 36:209-216.

Meirmans PG, Van Tienderen P. 2004. Genotype and genodive: two programs for the analysis of genetic diversity of asexual organisms. Molecular Ecology 4:792-794.

Montalvo AM, Williams SL, Rice KJ, Buchmann SL, Cory C, Handel SN, Nabhan GP, Primack R, Robichaux RH. 1997. Restoration biology: A population biology perspective. Restoration Ecology 5:277-290.

542 Oetjen K, Reusch TBH. 2007. Identification and characterization of 14 polymorphic ESTderived microsatellites in eelgrass (Zostera marina). Molecular Ecology Notes 7:777-780

544 Olsen J, Coyer J, Chesney, B. 2014. Numerous mitigation transplants of the eelgrass Zostera marina in southern California shuffle genetic diversity and may promote hybridization with Zostera pacifica. Biological Conservation 176:133-143.

547 Orth RJ, Carruthers TJB, Dennison WC, Duarte CM, Fourqurean JW, Heck KL, Hughes AR, 548 Kendrick GA, Kenworthy WJ, Olyarnik S, Short FT, Waycott M, Williams SL. 2006. A 
global crisis for seagrass ecosystems. American Institute of Biological Sciences 56:987996.

551 Ort BS, Cohen CS, Boyer KE, and Wyllie-Echeverria S. 2012. Population structure and genetic

552

553

554

555

556

557

558

559

560

561

562

563

564

565

566

567

568

569

570

571 diversity among eelgrass (Zostera marina) beds and depths in San Francisco Bay. Journal of Heredity 103:533-546.

Piazzi L, Balestri E, Magri M, Cinelli F. 1998. Experimental transplanting of Posidonia oceanica (L.) Delile into a disturbed habitat in the Mediterranean Sea. Botanica Marina 41:593601.

Oetjen K, Reusch TBH. 2007. Identification and characterization of 14 polymorphic ESTderived microsatellites in eelgrass (Zostera marina). Molecular Ecology Notes 7:777780.

Reusch TBH, Stam WT, Olsen JL. 1999. Microsatellite loci in eelgrass Zostera marina reveal marked polymorphism within and among populations. Molecular Ecology 8:317-321.

Reusch TB. 2000. Five microsatellite loci in eelgrass Zostera marina and a test of cross-species amplification in Z. noltii and Z. japonica. Molecular Ecology 9:371-373.

Reusch TBH, Ehlers A, Hammerli A, Worm B, Lubchenco J. 2005. Ecosystem recovery after climatic extremes enhanced by genotypic diversity. Proceedings of the National Academy of Sciences 102:2826-2831.

Reynolds KL, Waycott M, McGlathery KJ, Orth RJ, Zieman JC. 2012. Eelgrass restoration by seed maintains genetic diversity: case study from a coastal bay system. Marine Ecology Progress Series 448:223-233.

Salo T, Pedersen MF, Bostrom, C. 2014. Population specific salinity tolerance in eelgrass (Zostera marina). Journal of Experimental Marine Biology and Ecology 461:425-429. 
572 Salo T, Reusch TBH, Bostrom C. 2015. Genotype-specific responses to light stress in eelgrass

573 Zostera marina, a marine foundation plant. Marine Ecology Progress Series 519:129-140.

574 Short FT, Wyllie-Echeverria S. 1996. Natural and human-induced disturbance of seagrasses.

$575 \quad$ Environmental Conservation 23:17-27.

576 Short FT, Davis RC, Koss BS, Short CA, Burdick DM. 2002a. Site selection model for optimal

577 transplantation of eelgrass Zostera marina in the northeastern US. Marine Ecology

$578 \quad$ Progress Series 227:253-267.

579 Short FT, Short CA, Burdick-Whitney CL. 2002b. A Manual for Community-Based Eelgrass

580 Restoration, NOAA Restoration Center Report. University of New Hampshire, Durham, $581 \quad$ pp. 57 pp.

582 Short FT, Polidoro B, Livingstone SR, Carpenter KE, Bandeira S, Bujang JS, Calumpong HP, 583 Carruthers TJB, Coles RG, Dennison WC, Erftemeijer PLA, Fortes MD, Freeman AS, 584 Jagtap TG, Kamal AHM, Kendrick GA, Kenworthy WJ, La Nafie YA, Nasution IM, 585 Orth RJ, Prathep A, Sanciangco JC, van Tussenbroek B, Vergara SG, Waycott M, 586 Zieman JC. 2011. Extinction risk assessment of the world's seagrass species. Biological 587 Conservation 144:1961-1971.

588 Short FT, Burdick DM, Moore GE. 2012. The Eelgrass Resource of Southern New England and 589 New York: Science in Support of Management and Restoration Success. The Nature $590 \quad$ Conservancy. 93 pp.

591 Staehr PR, Borum J. 2011. Seasonal acclimation in metabolism reduces light requirements of 592 eelgrass (Zostera marina). Journal of Experimental Marine Biology and Ecology 593 407:139-146. 
594 Thom RM, Diefenderfer HL, Vavrinec J, Borde AB. 2012. Restoring resiliency: case studies 595 from Pacific Northwest estuarine eelgrass (Zostera marina L.) ecosystems. Estuaries and $596 \quad$ Coasts 35:78-91.

597 Tomas F, Abbott JM, Steinberg C, Balk M, Williams SL, Stachowicz JJ. 2011. Plant genotype 598 and nitrogen loading influence seagrass productivity, biochemistry, and plant-herbivore $599 \quad$ interactions. Ecology 92:1807-1817.

600 van Katwijk MM, Schmitz GHW, Hanssen LSAM, den Hartog C. 1998. Suitability of Zostera 601 marina populations for transplantation to the Wadden Sea as determined by a mesocosm 602 shading experiment. Aquatic Botany 60:283-305.

603 van Katwijk MM, Bros AR, de Jonge VN, Hanssen LSAM, Hermus DCR, de Jong DJ. 2009.

604 Guidelines for seagrass restoration: importance of habitat selection and donor population, 605 spreading of risk, and ecosystem engineering effects. Marine Pollution Bulletin 58:179$606 \quad 188$.

607 van Katwijk MM, Thorhaug A, Marbà N, Orth RJ, Duarte CM, Kendrick GA, Althuizen IHJ, 608 Balestri E, Bernard G, Cambridge ML, Cunha A, Durance C, Giesen W, Han Q, 609 Hosokawa S, Kiswara W, Komatsu T, Lardicci C, Lee K.-S, Meinesz A, Nakaoka M, 610 O'Brien KR, Paling EI, Pickerell C, Ransijn AMA, Verduin JJ. 2016. Global analysis of 611 seagrass restoration: the importance of large-scale planting. Journal of Applied Ecology 612 $53: 567-578$.

613 Waycott M, Duarte CM, Carruthers TJ, Orth RJ, Dennison WC, Olyarnik S, Calladine A, 614 Fourqurean JW, Heck KL, Hughes AR, Kendrick GA. 2009. Accelerating loss of 615 seagrasses across the globe threatens coastal ecosystems. Proceedings of the National 616 Academy of Sciences 106:12377-12381. 
617 Williams SL. 2001. Reduced genetic diversity in eelgrass transplantations affects both

618 population growth and individual fitness. Ecological Applications 11:1472-1488.

619 Wilkinson CR. 2008. Status of coral reefs of the world: 2008. Global Coral Reef Monitoring 620 Network and Reef and Rainforest Research Centre, Townsville, Australia.

621 Zhou Y, Liu P, Liu B, Liu X, Zhang X, Wang F, Yang H. 2014. Restoring eelgrass (Zostera

622 marina $\mathrm{L}$ ) habitats using a simple and effective transplanting technique. PLoS One. 9: $623 \quad$ e92982.

624

625

626

627

628

629 
Table 1. Environmental conditions at source population sites for 2013-2014.

\begin{tabular}{|c|c|c|c|c|c|c|c|}
\hline Site & $\begin{array}{l}\text { Tidal } \\
\text { range }\end{array}$ & $\begin{array}{c}\text { Wave } \\
\text { Exposure }\end{array}$ & $\begin{array}{c}\text { Temperature } \\
\left({ }^{\circ} \mathrm{C}\right)\end{array}$ & $\begin{array}{l}\text { Salinity } \\
\text { (psu) }\end{array}$ & Substrate & $\begin{array}{c}\text { Total Nitrogen } \\
(\mu \mathrm{m})\end{array}$ & Comments \\
\hline $\begin{array}{l}\text { Dorothy Cove, } \\
\text { Nahant }\end{array}$ & 3 to $4 \mathrm{~m}$ & Moderate & -1 to 21 & 30 to 32 & $\begin{array}{c}\text { Sand } \\
<2 \% \mathrm{OM}\end{array}$ & 25 to 34 & $\begin{array}{l}\text { Storm Water pipe } \\
\text { at site }\end{array}$ \\
\hline $\begin{array}{l}\text { East Harbor, } \\
\text { North Truro }\end{array}$ & $0.3 \mathrm{~m}$ & Low & 0 to 29 & 20 to 30 & $\begin{array}{c}\text { Sand } \\
<2 \% \mathrm{OM}\end{array}$ & 20 to 47 & $\begin{array}{l}\text { Tidally restricted; } \\
\text { shallow embay- } \\
\text { ment; } 1(\mathrm{Ha}) \\
\text { eelgrass bed } \\
\text { established } 2008\end{array}$ \\
\hline $\begin{array}{l}\text { Pleasant Bay, } \\
\text { Orleans }\end{array}$ & $2 \mathrm{~m}$ & Low & 0 to 30 & 28 to 32 & $\begin{array}{c}\text { Sand } \\
<2 \% \mathrm{OM}\end{array}$ & 28 to 34 & $\begin{array}{l}\text { low flushing; } \\
\text { shallow embay- } \\
\text { ment; Thriving } \\
40 \text { (Ha) bed }\end{array}$ \\
\hline $\begin{array}{l}\text { Sea Gull Beach, } \\
\text { West Yarmouth }\end{array}$ & $3 \mathrm{~m}$ & High & -2 to 24 & 30 to 32 & $\begin{array}{c}\text { Sand } \\
<2 \% \mathrm{OM}\end{array}$ & 6to 18 & shifting substrate \\
\hline
\end{tabular}

Source: Temperature and salinity for Dorothy Cove is from the Boston Harbor NDBC NOAA buoy; temperature and salinity data for East Harbor and Pleasant

Harbor, Pleasant Bay, and Sea Gull Beach courtesy of CCNS-NPS, Pleasant Bay Alliance, and the Massachusetts Estuaries' Project (Dates 2012-2014). 
636 Table 2: Indices of genetic diversity by source population. N= number of genotyped shoots; $\mathrm{R}=$ 637 clonal richness, calculated as $(\mathrm{G}-1) /(\mathrm{N}-1)$, where $\mathrm{G}$ is the number of unique MLGs sampled; $\mathrm{H}^{\prime}=$ 638 Shannon index of clonal diversity; $E D^{*}=$ Simpson's evenness index (clonal evenness); $\mathrm{N}_{\mathrm{a}}=$ mean 639 number of alleles per loci; $\mathrm{Ne}=$ effective number of alleles per loci, $\mathrm{Ho}=$ observed 640 heterozygosity, $\mathrm{He}=$ expected heterozygosity, $\mathrm{F}_{\mathrm{is}}=$ inbreeding coefficient.

641

642

\begin{tabular}{lccccccccc}
$\begin{array}{l}\text { Source } \\
\text { Population }\end{array}$ & $\mathbf{N}$ & $\mathbf{R}$ & $\mathbf{H}$ & $\mathbf{E D}$ & $\mathbf{N a}$ & $\mathbf{N e}$ & $\mathbf{H o}$ & $\mathbf{H e}$ & $\mathbf{F}_{\text {is }}$ \\
\hline Nahant & 22 & 0.48 & 2.02 & 0.56 & 4.2 & 2.98 & 0.57 & 0.55 & -0.023 \\
East Harbor & 23 & 0.45 & 1.87 & 0.32 & 4.1 & 2.55 & 0.61 & 0.52 & -0.174 \\
Pleasant Bay & 23 & 0.82 & 2.87 & 0.66 & 6.1 & 3.72 & 0.71 & 0.65 & -0.090 \\
West Yarmouth & 23 & 0.82 & 2.89 & 0.79 & 5.1 & 2.54 & 0.58 & 0.53 & -0.096
\end{tabular}

643

644

645 
646 Table 3. Analysis of Variance on the mean number of shoots remaining per cross-hair at both 647 sites in (A) March (four months), (B) May (six months), and (C) June (seven months post648 transplantation).

649

650

651

652

653

654

655

656

657

658

659

660

661

662

663

664

665

666

667

668

669

670

671

672

673

674

675

676

677

\begin{tabular}{lllcc} 
A. Source & $\boldsymbol{d} \boldsymbol{f}$ & S-of-S & F-ratio & $\boldsymbol{p}$ \\
\hline site & 1 & 0.136 & 3.098 & 0.086 \\
source population & 3 & 2.481 & 18.877 & $<\mathbf{0 . 0 0 0 1}$ \\
source diversity & 1 & 0.743 & 16.968 & $\mathbf{0 . 0 0 0 2}$ \\
$\quad$ site x source population & 3 & 0.140 & 1.062 & 0.376 \\
$\quad$ site x source diversity & 1 & 0.154 & 3.522 & 0.068 \\
$\quad$ source population x source diversity & 3 & 0.534 & 4.066 & $\mathbf{0 . 0 1 3}$ \\
$\quad$ site x source pop'n x diversity & 3 & 0.218 & 1.661 & 0.191
\end{tabular}

\begin{tabular}{lllcc} 
B. Source & $\boldsymbol{d} \boldsymbol{f}$ & S-of-S & F-ratio & $\boldsymbol{p}$ \\
\hline site & 1 & 0.828 & 8.983 & $\mathbf{0 . 0 0 5}$ \\
source population & 3 & 5.601 & 20.267 & $<\mathbf{0 . 0 0 0 1}$ \\
source diversity & 1 & 0.0001 & 0.002 & 0.965 \\
$\quad$ site x source population & 3 & 2.092 & 7.567 & $\mathbf{0 . 0 0 0 3}$ \\
$\quad$ site x source diversity & 1 & 0.044 & 0.482 & 0.491 \\
$\quad$ source population x source diversity & 3 & 0.065 & 0.236 & 0.870 \\
$\quad$ site x source pop'n x diversity & 3 & 0.557 & 2.013 & 0.126
\end{tabular}

\begin{tabular}{lllcc} 
C. Source & $\boldsymbol{d} \boldsymbol{f}$ & S-of-S & F-ratio & $\boldsymbol{p}$ \\
\hline site & 1 & 1.942 & 24.717 & $<\mathbf{0 . 0 0 0 1}$ \\
source population & 3 & 0.783 & 3.321 & $\mathbf{0 . 0 2 7}$ \\
source diversity & 1 & 0.062 & 0.791 & 0.378 \\
$\quad$ site x source population & 3 & 0.989 & 4.195 & $\mathbf{0 . 0 1 0}$ \\
$\quad$ site x source diversity & 1 & 0.296 & 3.762 & 0.058 \\
$\quad$ source population x source diversity & 3 & 0.209 & 0.885 & 0.455 \\
$\quad$ site x source pop'n x diversity & 3 & 0.186 & 0.788 & 0.506
\end{tabular}


678 Figure 1. Location of the source and transplant sites. Note: East Harbor and Pleasant Bay 679 served as source and transplant sites. Distances between sites are denoted in Table S2. Source: 6802015 DigitalGlobe.

681

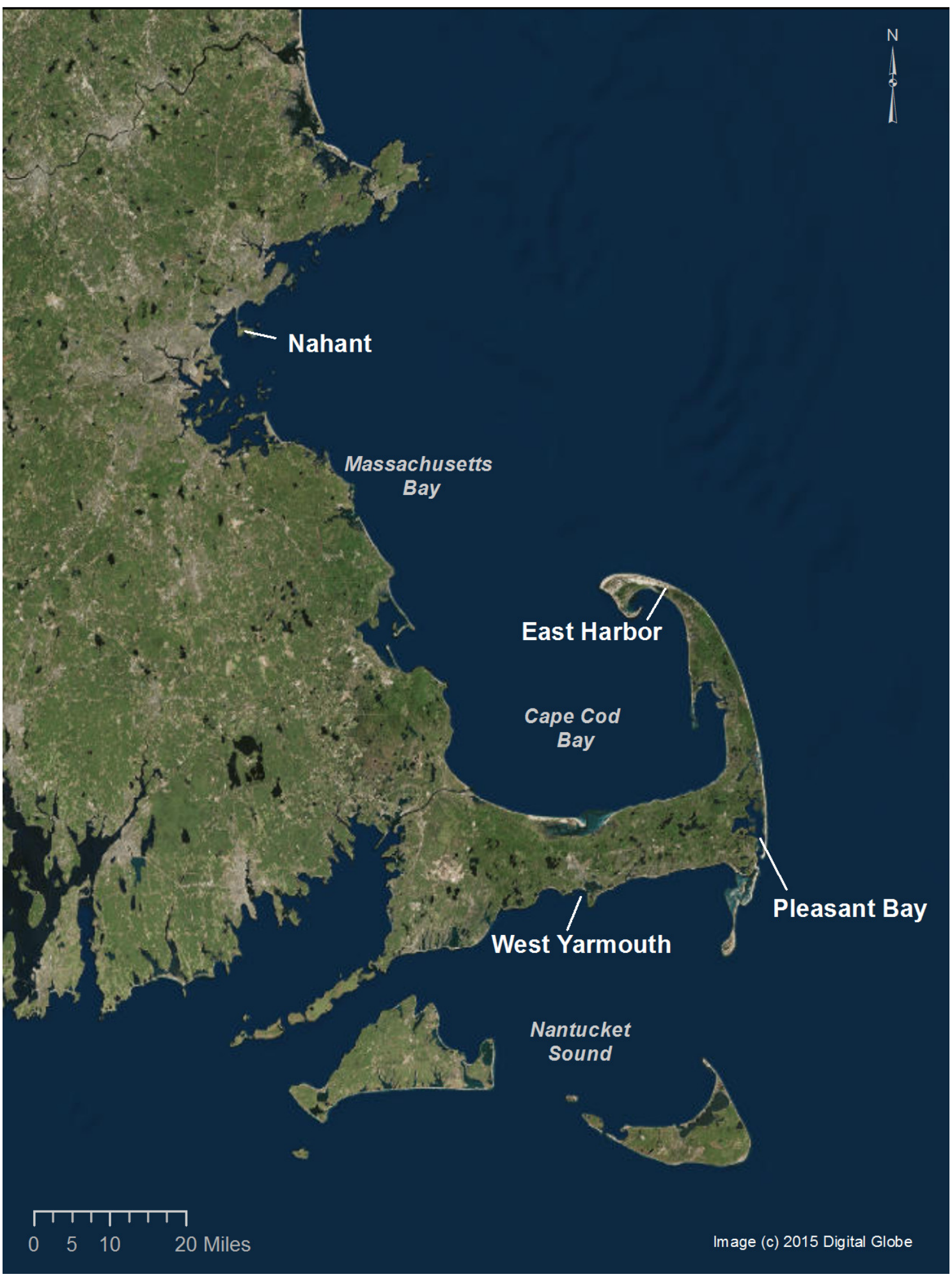


684 Figure 2. Differences in shoot morphology among the four source populations at start of field 685 experiment. Significant differences were observed among source populations at $p<0.05$ (means $686 \pm \mathrm{SE}$ ); n=25; Tukey's results denoted by letters (A-C).

687

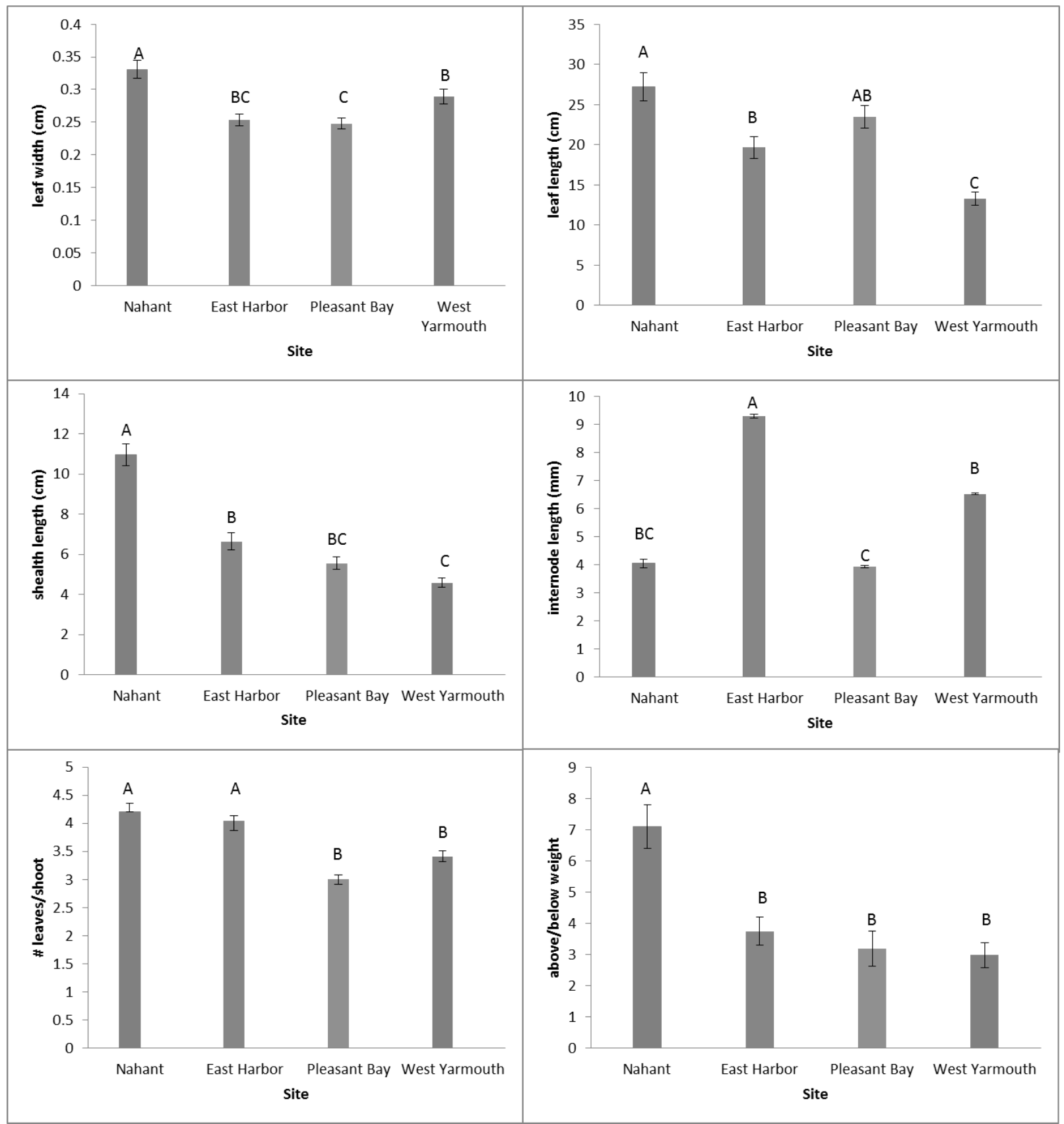


690

691

692

693

Figure 3. Shoot density for each single source plot at each site (Nahant (N); East Harbor (EH); Pleasant Bay (PB); West Yarmouth (WY)). Significant differences were observed among treatments in March and May at East Harbor at $p<0.05$ (means \pm SE ); $n=3-4$; Tukey's results denoted by letters (A-C). Home source populations shaded dark gray for each site.

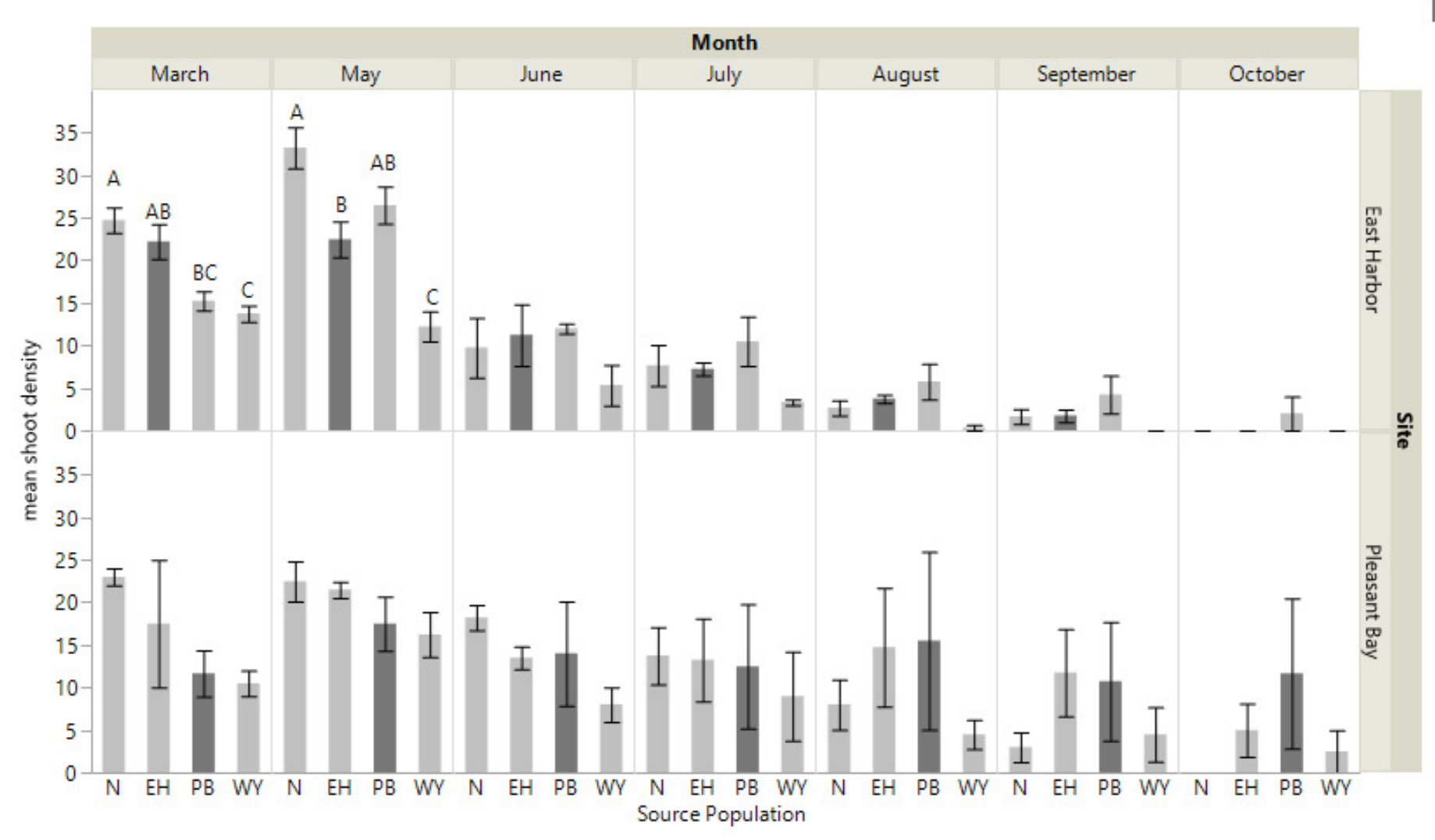


698 Figure 4. Mean shoot density values per plot at each site for single source and multiple source 699 plots for the months March and May thru October. Significant differences were observed

700 between treatments only at East Harbor (denoted by solid bar) at $p<0.05$ (means $\pm \mathrm{SE}$ ); $\mathrm{n}=4$ for

701 all months at each site except in March at Pleasant Bay where $n=3$ ).

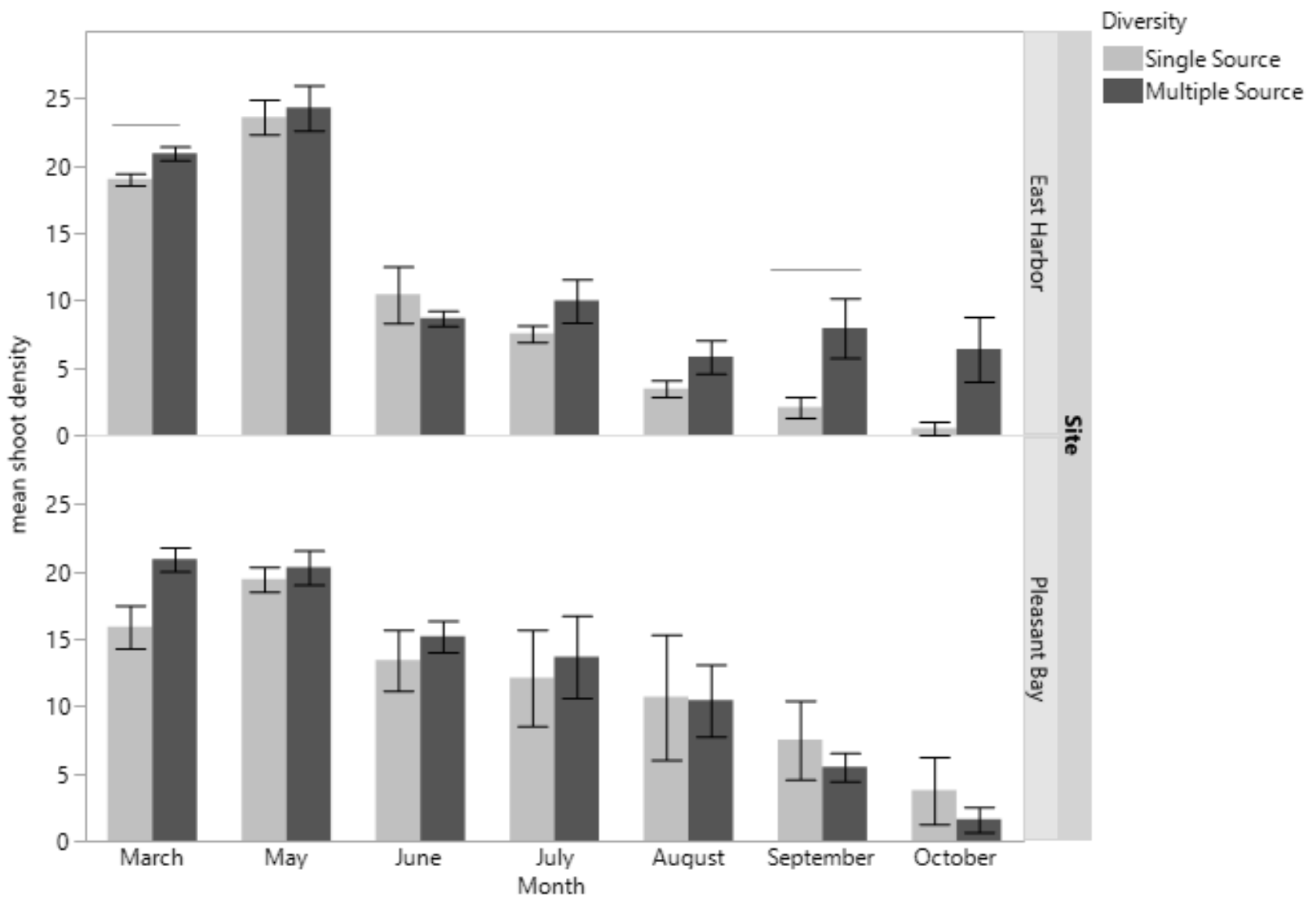


711 Figure 5. Effect of source population and source diversity on mean number of shoots per cross712 hair four months after transplantation (March). Both transplant sites are pooled. Solid bars 713 indicate significant differences in shoot performance between single source treatments and 714 multiple source treatments (a priori contrasts, $p<0.05$; means $\pm \mathrm{SE}$ ).

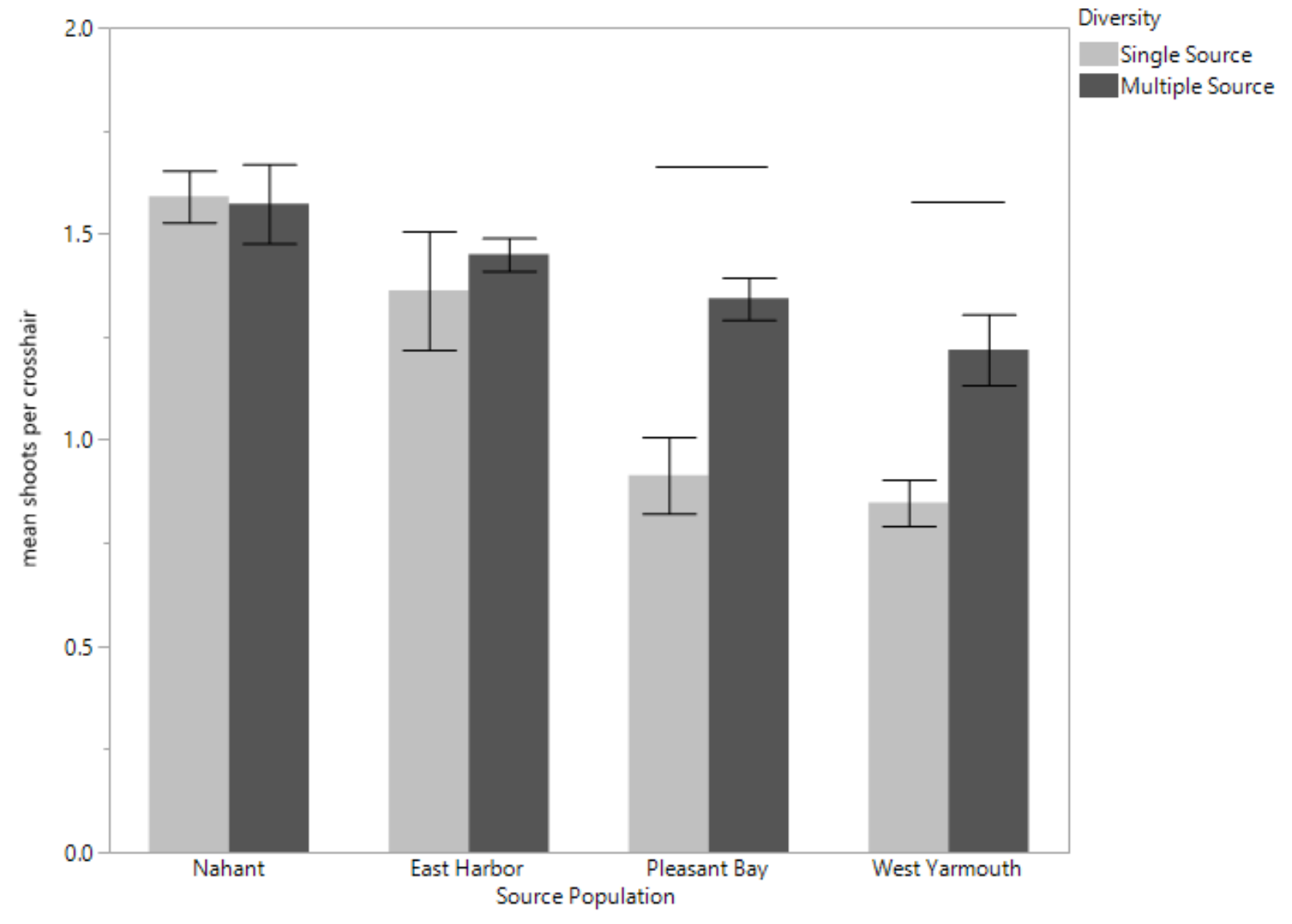

